\title{
Extensive spinal cord involvement in magnetic resonance imaging evaluation on schistosomal myelitis
}

\author{
Envolvimento difuso da medula espinhal na avaliação pela ressonância magnética da \\ mielite esquistossomótica
}

Claudio Henrique Fernandes Vidal', Maria Lucia Brito Ferreira², Hildo Rocha Cirne de Azevedo Filho ${ }^{1,3}$, Fernando Viana Gurgel ${ }^{4}$, Alessandra Mertens Brainer-Lima ${ }^{4}$

\begin{abstract}
The diagnosis of schistosomal myelitis (SM) is frequently presumptive because no findings from any complementary examination are pathognomonic for this disease. The present report describes some abnormalities seen on magnetic resonance imaging (MRI) evaluation of a series of SM patients and discusses their etiopathogenesis. Methods: This study evaluated SM patients at the time of their diagnosis. These patients routinely underwent MRI on all segments of the spinal cord. Results: Thirteen patients were evaluated. The MRI was abnormal in 12 (92.3\%) of them. In 11 patients (84.61\%), the damage reached two or more spinal segments. Conclusions: MRI was an important diagnostic aid in this sample, because of the high rate of abnormalities detected. The tissue damage observed on MRI was extensive in the majority of the patients.
\end{abstract}

Key words: Schistosoma mansoni, neuroschistosomiasis, myelitis, magnetic resonance imaging, diagnosis.

\section{RESUMO}

O diagnóstico da mielite esquistossomótica é frequentemente realizado por presunção, não havendo achado de exame complementar que seja patognomônico à condição. O presente estudo descreve alterações presentes na avaliação desses pacientes pela técnica da ressonância magnética e discute sua etiopatogênese. Métodos: 0 estudo avaliou pacientes com mielite esquistossomótica no momento do diagnóstico, os quais foram submetidos, rotineiramente, à ressonância magnética de todos os segmentos medulares. Resultados: Foram avaliados 13 pacientes, sendo a ressonância magnética alterada em 92.3\% dos casos. Em 11 pacientes (84.61\%), o dano abrangeu dois ou mais segmentos espinais. Conclusões: A ressonância magnética espinhal foi um importante auxílio diagnóstico nessa casuística em virtude da alta taxa de alterações detectadas. 0 dano tecidual observado foi extenso na maioria dos pacientes.

Palavras-Chave: Schistosoma mansoni, neuroesquistossomose, mielite, imagem por ressonância magnética, diagnóstico.

Schistosomiasis is a serious public health problem in some regions of the world. It is endemic in more than 74 countries and accounts for the majority of the cases of portal hypertension among the young population in these areas. Around the world, it is believed that there are about 200 million people infected by the Schistosoma species S. mansoni, S. haematobium, S. japonicum, S. intercalatum and S. mekongi ${ }^{1,2}$.

The temporal clinical and systemic forms of the disease are: acute (toxemic and non-toxemic), latent and chronic ${ }^{2,3}$. The latter is divided into mild forms (intestinal and hepatic- intestinal) and severe forms (hepatosplenic, pulmonary and glomerular $)^{2,3}$.

The presence and clinical significance of neurological lesions depend on the combination of the presence of eggs in the nervous system and the immune response of the host. In the majority of cases, a type IV or granulomatous delayed immune response occurs, and the response is greater in the earlier phases of schistosomiasis. In chronic forms, it becomes localized and attenuated (immunological modulation phenomenon) $)^{4,5}$.

\footnotetext{
${ }^{1}$ Postgraduate Program on Neuropsychiatry and Behavioral Sciences, Health Sciences Center, Federal University of Pernambuco (UFPE), Recife PE, Brazil; ${ }^{2}$ Head of Neurology Department, Hospital da Restauração, Recife PE, Brazil;

${ }^{3}$ Head of Neurosurgery Department, Hospital da Restauração, Recife PE, Brazil;

${ }^{4}$ Radiologist, Hospital da Restauração, Recife PE, Brazil.

Correspondence: Claudio Henrique Fernandes Vidal; Rua Francisco da Cunha 206; 51020-041 Recife PE - Brasil; E-mail:vidal-claudio@ig.com.br

Conflict of interest: There is no conflict of interest to declare.

Received 15 May 2011; Received in final form 14 November 2011; Accepted 22 November 2011
} 
The diagnosis of schistosomal myelitis (SM) is frequently made by presumption, because no findings from any complementary examinations can be considered to be pathognomonic for this condition ${ }^{6}$. The present report describes some abnormalities seen on magnetic resonance imaging (MRI) evaluation of a series of SM cases and discusses their etiopathogenesis.

\section{METHODS}

The study protocol was approved by the institutional review board of the participating center (Hospital da Restauração; CAAE 0033.0.102.172-05), and the patients gave written consent for their inclusion in the data analysis.

This study was a cross-sectional and descriptive evaluation on a case series from a hospital database, in which the sample consisted of individuals infected with Schistosoma mansoni at the time when myelitis was diagnosed. The patients were admitted to the neurological ward between July 2005 and June 2006.

The inclusion criteria used were the diagnostic recommendations from the Centers for Disease Control (CDC)7: dysfunction of thoracic or lumbosacral spinal cord; parasitological confirmation of infection by Schistosoma mansoni and exclusion of other causes of transverse myelitis.

Positive epidemiological findings of schistosomiasis were a basic requirement. The patients that fulfilled this criterion had been in contact with still water bodies that contained the snail. Parasitological confirmation was also necessary. For this purpose, each patient provided three stool samples (from different days) and the Kato-Katz method was applied to detect worm eggs. Presence of eosinophils in cerebrospinal fluid with an immunological reaction to schistosomiasis antigens was also considered to be parasitological evidence of this disease independently of the result from the stool analysis.

Other causes of transverse myelitis were ruled out by using anamnesis, with emphasis on vasculitis and other autoimmune diseases. Patients were excluded if there were any of the following findings: 1 . neurological complaints lasting for more than 15 days; 2. presence of fever or another acute inflammatory or infectious condition; 3. vaccination or infectious disease within 15 days prior to the beginning of the

Table. Spinal cord magnetic resonance image alterations.

\begin{tabular}{lcc}
\multicolumn{1}{c}{ Examination } & $\mathrm{n}$ & $\%$ \\
\hline Signal change & 12 & 92.30 \\
Contrast enhancement & 8 & 66.66 \\
Spinal segment of the disease & & \\
Cervical/thoracic/lumbar & 4 & 33.33 \\
Thoracic & 1 & 8.33 \\
Thoracic/lumbar & 6 & 50 \\
Conus medullaris & 1 & 8.33 \\
\hline
\end{tabular}

complaints; 4. immunological positive reaction in the cerebrospinal fluid analyses to other parasitic or viral antigens; or 5. evidence of intrathecal syntheses of proteins or presence of oligoclonal bands. No blood serological markers of autoimmune disease were investigated.

All patients underwent MRI of the cervical-dorsal-lumbar spine soon after the clinical diagnosis of myelitis had been made (usually less than seven days) and were examined using MRI units rated at 1.5T. Surface coils were used for all patients. Fast T2-weighted spin-echo imaging was performed by using a TR of $2500 \mathrm{~ms}$ and a TE of $120 \mathrm{~ms}$ in the sagittal and axial planes. All patients were examined using T1-weighted TR/TE (400-600/20-25 ms) in the sagittal, axial and coronal planes, before and after receiving $0.1 \mathrm{mmol} / \mathrm{kg}$ of gadolinium injected intravenously for one minute. The mean duration of each examination was between 15 and 20 minutes. The spinal cord segments were named according to their relationship with bony spinal segments, except for the conus medullaris.

\section{RESULTS}

A total of 13 patients were evaluated during the study period. The gender distribution was very similar $(53.84 \%$ males and $46.15 \%$ females). The mean age among the patients was 27.31 years (with a minimum of 15 and a maximum of 47 years).

The MRI was abnormal in $92.3 \%$ of the cases, and a diffuse hypersignal on T2 was the most common finding. Mild diffuse heterogeneous enhancement was observed in $66.66 \%$ of the abnormal cases. In four cases (33.33\%), the signal change on the T2 sequence included all segments of the spine (cervical, thoracic and lumbar). In six cases (50\%), the thoracic and lumbar segments were both involved. The thoracic segment and the conus medullaris were involved alone in just one case each ( $8.33 \%$ ). The data on the MRI abnormalities are described briefly in the Table, and the Figure shows a typical examination from this series (Table) (Figure).

The case with thoracic involvement alone extended from T1 to T11. Among the patients with thoracic-lumbar involvement, the extent of the involvement was: one from $\mathrm{T} 1$ to conus medullaris; one from $\mathrm{T} 2$ to the conus medullaris; one from T6 to the conus medullaris; and three from T8 to the conus medullaris. There were no characteristic patterns of contrast enhancement in this series, except for diffuse heterogenic enhancement, neither any pseudotumoral form documented.

\section{DISCUSSION}

The classical abnormalities seen on MRI in SM cases are hyposignal on $\mathrm{T} 1$ sequences, hypersignal on $\mathrm{T} 2$ sequences and heterogenic enhancement during the contrast phase ${ }^{8,9}$. 

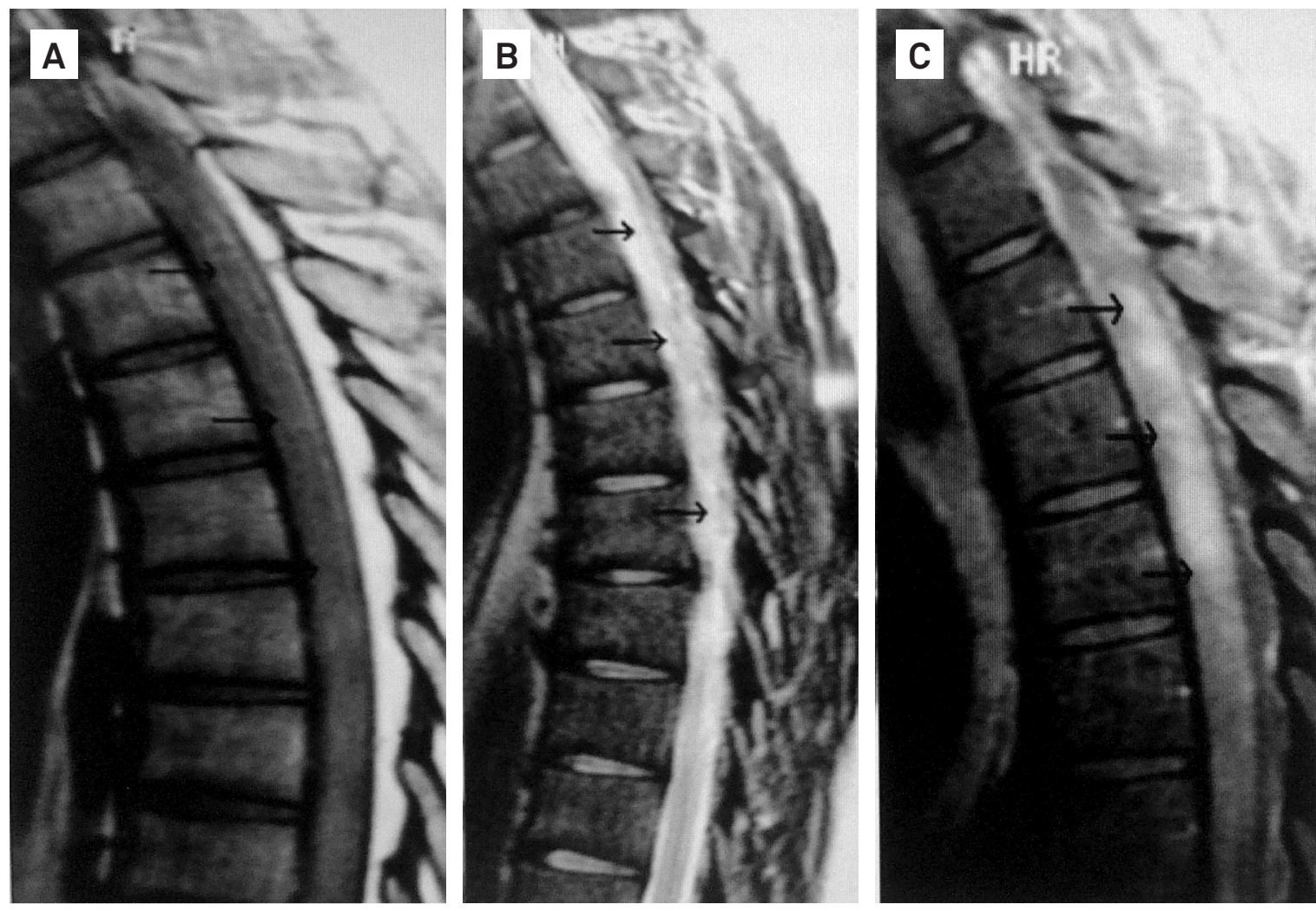

Figure. High thoracic involvement is shown in this magnetic resonance image sequence. (A) The arrows show hyposignal on T1 sequence. (B) The arrows show hypersignal on T2 sequence. (C) The arrows show diffuse heterogenic enhancement during the contrast phase.

In the present series, the MRI was abnormal in $92.3 \%$ of the cases, and a diffuse hypersignal on $\mathrm{T} 2$ was the most common finding. Mild diffuse heterogenic enhancement was observed in $66.66 \%$ of the abnormal cases. Peregrino et al. ${ }^{8}$ and Correia et al. ${ }^{10}$ reported positive findings in 88.8 and $91.9 \%$ of their cases, respectively.

The patients in the current study were evaluated less than seven days after the onset of symptoms. Some false-negative findings on MRI, like a normal examination in one case and non-contrast enhancement in some patients, may be attributed to this early stage of the disease. Saleem et al. ${ }^{11}$ described some specific patterns of contrast enhancement in eight patients with SM which were not observed in the present sample. Nevertheless, some points have to be considered: 1. the mean duration of complaints in their report was seven months; 2 . there were some non-S. mansoni cases; 3 . it is possible that the majority of their patients developed the pseudotumoral form of the disease, which would explain the different pattern on MRI.

In four cases (33.33\%), the signal change on T2 sequences included all segments of the spine (cervical, thoracic and lumbar). In six cases (50\%), the thoracic and lumbar segments were both involved. The thoracic segment and the conus medullaris were solely involved in just one case each (8.33\%). The extension of tissue damage shown by MRI in this report was higher than what was previously described in the literature. Abnormalities above T11 are considered uncommon, and the uppermost level in Saleem's series ${ }^{11}$ was T9. Peregrino et al. ${ }^{8}$ reported that in $66.6 \%$ of their patients just the conus medullaris was involved, and no case of cervical involvement was described. Damage to the cervical segment has been described as very rare ${ }^{12}$, but Valença ${ }^{13}$ reported its occurrence and concluded that it is imperative to examine all segments using MRI among SM patients.

The tissue damage signal abnormalities observed using MRI were quite extensive in the majority of the patients in the present study. It is possible that inflammatory periovular granulomatous reactions alone would not be sufficient to explain this event. Immunocomplex deposition and vascular damage can participate to different degrees in relation to generating a broader inflammatory response along the neuroaxis ${ }^{3}$. None of the patients in this sample had any severe form of systemic schistosomiasis (hepatosplenic, pulmonary or glomerular) that could explain the diffuse dissemination of the eggs in collaterals along the neuroaxis.

The majority of the cases $(76.92 \%)$ in the present study came from a recent endemic area for schistosomiasis. These data reflect the urbanization process of schistosomiasis ${ }^{14}$. It is possible that the immune status before, during and after the development of the infection is the most important factor in determining the clinical forms of Schistosomiasis mansoni $^{3}$. The nervous system lesions are probably conditioned 
by this immunological context. Recent first-time exposure to contaminated waters among these patients could make them more susceptible towards developing a favorable immunological environment for promoting neurological damage. This differs from individuals who have been living in long-standing endemic zones for schistosomiasis, in which the contamination sometimes affects several generations of the same family ${ }^{2,3,14}$. This paradigm may explain the major spinal cord abnormalities observed in this sample and may represent a state of immunological hypersensitivity to the antigens and eggs of the worm.

The high abnormality rates in MRI examinations that were documented in this study suggest that this is an important diagnostic tool for suspected cases of SM and that all segments of the spinal cord should be included in this examination on a routine basis. The traditional concept of a process restricted to the lower spinal cord levels in MRI evaluations needs to be revised. Some clinical factors, such as the time elapsed from the first contact with the parasite antigens, the patient's age at the time of this first contact, the patient's origin and the duration of the complaints, should be taken into consideration during image analyses on SM cases.

In conclusion, MRI was an important auxiliary tool in diagnosing SM in this series. The tissue damage observed in the MRI evaluations on these neuroschistosomiasis cases was quite extensive, and, thus, all segments of the spinal cord should be added to this radiological examination on a regular basis. Further MRI studies regarding the length of evolution of this disease and with larger numbers of patients are needed to confirm the above hypothesis.

\section{References}

1. Doumenge JP, Mott KE, Chenng C, et al. Atlas de la repartition mondiale des schistosomiasis. Bordeux: Presses Universitaires de Bordeaux; 1987: 391-398

2. Coutinho AD, Domingues ALC. Esquistossomose mansoni. In: Dani R, Castro LP (Eds). Gastroenterologia clínica. Rio de Janeiro: Guanabara Koogan; 1993: 1697-1728.

3. Raso P. Esquistossomose Mansônica. In: Filho GB, (Ed). Bogliolo patologia. Rio de Janeiro: Guanabara Kookan; 2000: 1186-1207.

4. Pitella JE. The relation between involvement of the central nervous system in schistosomiasis mansoni and the clinical forms of the parasitosis. A review. J Trop Med Hyg 1991;94:15-21.

5. Ferrari TC, Moreira PR, Cunha AS. Spinal-cord involvement in the hepato-splenic form of Schistosoma mansoni infection. Ann Trop Med Parasitol 2001;95:633-635.

6. Santos EC, Campos GB, Diniz AC, Leal JC, Rocha MO. Perfil clínico e critérios diagnósticos da mielorradiculopatia esquistossomótica. Arq Neuropsiquiatr 2001;59:772-777.

7. Centers for Disease Control (CDC). Acute schistosomiasis with transverse myelitis in American students returning from Kenya [editorial note]. MMWR Morb Mortal Wkly Rep 1984;33:445-447.
8. Peregrino AJ, Puglia PM, Bacheschi LA, et al. Diagnóstico da esquistossomose medular: contribuição da ressonância magnética e eletroneuromiografia. Arq Neuropsiquiatr 2002;60:597-602.

9. Dupuis MJ, Atrouni S, Dooms GC, Gonsette RE. MR imaging of schistosomal myelitis. AJNR Am J Neuroradiol 1990;11: 782-783.

10. Correia CC, Ataíde Jr L, Lins OG, Ferreira MLB. Aspectos eletromiográficos preditores da evolução motora de pacientes com neuroesquistossomose. Arq Neuropsiquiatr 2007;65:130-133.

11. Saleem S, Belal Al, El-Ghandour NM. Spinal cord schistosomiasis: MR imaging appearance with surgical and pathologic correlation. AJNR Am J Neuroradiol 2005;26:1646-1654.

12. Silva LC, Kill CM, LambertucciJR. Cervical spinal cord schistosomiasis. Rev Soc Bras Med Trop 2002;35:543-544.

13. Valença MM. Correspondência. Critérios diagnósticos da esquistossomose mansônica meningomielorradicular. Arq Neuropsiquiatr 2002;60:181-182.

14. Vidal CH, Gurgel FV, Ferreira ML, Azevedo-Filho HR. Epidemiological aspects in neuroschistosomiasis. Arq Neuropsiquiatr 2010; $68: 72-75$ 